\title{
Pacto pela saúde: aproximações e colisões na arena federativa
}

\author{
Health pact: approaches and collisions in the federal arena
}

Telma Maria Gonçalves Menicucci ${ }^{1}$

Luciana Assis Costa ${ }^{2}$

José Ângelo Machado ${ }^{3}$

${ }^{1}$ Faculdade de Filosofia e Ciências Humanas, Universidade Federal de Minas Gerais (UFMG). Av. Antonio Carlos 6627, Campus Pampulha. 31270901 Belo Horizonte MG Brasil.telmenicucci@ fafich.ufmg.br

${ }^{2}$ Escola de Educação Física, Fisioterapia e Terapia Ocupacional, UFMG. Belo Horizonte MG Brasil.

${ }^{3}$ Faculdade de Filosofia e Ciências Humanas, UFMG. Belo Horizonte MG Brasil.
Abstract This article analyze the institutional construction process of the Health Pact, consolidated in 2006 and that expresses an incremental evolution of the regulatory framework of federative relationships in Brazilian National Health System. Even considering that such process has developed in a federative parity arena (CIT) it is assumed the general hypothesis of Brazilian literature about federalism that suggests the Federal Government dominant role in the formulation of social policies. Using an institutionalist approach, focusing on the relationship between Federalism and Public Policy it was done a qualitative study starting from semi-structured interviews with managers and consultants who participated in the process and analyzing the minutes of meetings from CIT between 2004-2012. The results indicate: the federal government held the formulation initiative, but there was reasonable influence of sub national governments; the long discussions period reflected a high degree of dissent between the federated entities; as a result, the question of financing was transferred to a political commitment for expansion of funding sources to be assumed by the three spheres of government; the Health Pact did not change the dynamics federative relations regarding the frame of regional health care networks.

Key words Health policy, Federalism, Public policy
Resumo O artigo analisa o processo de construção institucional do Pacto pela Saúde consolidado em 2006, e que expressa uma evolução incremental do arcabouço regulatório das relações federativas no SUS. Ainda que considerando que tal processo se desenvolveu de forma privilegiada, numa arena federativa paritária - a CIT-, assume-se a hipótese geral da literatura brasileira sobre federalismo que sugere um papel dominante da União na formulação das politicas sociais. Utilizando a abordagem institucionalista, com foco na relação entre federalismo e politicas públicas, realizouse um estudo qualitativo a partir de entrevistas com gestores e consultores que participaram do processo, e análise das atas de reuniões da CIT (2004-2012). Os resultados apontam: a União foi detentora da iniciativa de formulação, mas houve razoável influência dos governos subnacionais; o longo período de discussões refletiu alto grau de dissenso entre os entes federados; na ausência de consenso, a questão do financiamento foi transferida para um compromisso politico pela ampliação das fontes de financiamento a ser assumido pelas três esferas de governo; o Pacto não modificou a dinâmica das relações federativas quanto à conformação das redes regionais de atenção à saúde.

Palavras-chave Politica de saúde, Federalismo, Política pública 


\section{Introduction}

Brazil has one of the most decentralized health systems in the world, with municipalities playing a central role in implementing the policy and the provision of health services. However, in addition to regional and local differences between health needs, differences in the availability of resources and ability to provide services were added to the underfunding of the sector, producing regional imbalances and significant challenges for system management. Health care organization is especially sensitive to these aspects, since it depends on the installation of a network of diverse services, distributed at different levels of complexity, dispersed geographically and acting in various scales depending on the degree of complexity and demand.

In addition, the federal context under which the network services are comprised must be considered, as well as decentralization. The management in this context stresses the need to combine autonomy of federal entities and coordination between them in order to ensure, regardless of territorial location of residences, access for all and at all levels of care complexity. It relates to coordinating resources and services under the responsibility of several managers, integrating them under pre-set criteria and flows.

Over the past two decades, the SUS institutional organization was modified in order to improve such integration, it being relevant to mention the Basic Operational Norm 01/1996, the Operational Norm of Health Care 01/2002 and the Pact for Health ${ }^{1}$. The latter expresses an incremental improvement over the preceding standards, while bringing forth important qualitative changes in its design aimed to promote "innovation in processes and management tools" and "to redefine collective responsibilities for health outcomes due to the population's needs and the pursuit of social equity"1.

Improvements and definitions of sanitary and management responsibilities were designed under the three components that made up the Pact for Health: the Pact for Life, the SUS Defense Pact and the Management Pact. The Pact for Life consisted of the compromise between SUS managers regarding impact priorities on the Brazilian population's health status. The SUS Defense Pact involved concrete actions articulated by the three federal bodies to strengthen SUS as a State policy. The SUS Management Pact brought changes in the previous rules in order to strengthen the regionalization strategy, contributing to strength- ening the so-called Shared and Unified SUS management $^{1}$.

The objective of this study was to analyze the institutional building process of the Health Pact, consolidated in 2006, understood as the production of agreements on rules that define the responsibilities and resources available to entities linked to the management of health care networks at every government level. Although considering that this process was developed in a privileged manner in a joint federal arena of the Tri-partite Management Commission (CIT), Brazilian literature on federalism has suggested a leading role of the Union in forming and coordinating social policies, a point that we take here as a general hypothesis. Unlike previous studies that emphasized the implementation aspects ${ }^{2}$ or results ${ }^{3}$, the present study aims to elucidate tensions and convergences between government levels in the Health Pact institutional construction process. Health policy in Brazil offers a fertile field for reflecting on the conditions and possible solutions of federal dilemmas, which is why we started this work by characterizing the distribution of vertical political authority between the three levels of government in the institutional configuration that emerged from the 1988 Federal Constitution. Next, we describe the methodology of the work and its results, followed by the discussion and conclusion.

\section{Federal dilemmas and federal relations in the SUS}

Despite conceptual differences, the common ground between the various definitions of federalism is that it organizes the State into two or more levels of government which have formal authority over their territorial space and citizens $s^{4}$. By constitutionally guaranteeing spaces for independent action to each level of government, it would be expected that this would promote some level of power dispersion. It would involve a pact that assumes cooperation and reciprocity between the federal entities, as well as partial assignment of autonomy of the constituent parts at the same time in order to achieve collective public well-being ${ }^{5-7}$. Not only would the forms and contents of space be shared between federal entities, but also their degree of autonomy would vary significantly between different federations. Such sharing requires solving coordination problems between different levels of government, possibly in constitutional and legal constraints and under the regulation of instruments managed at a na- 
tional level, in order to induce cooperation, however, without hurting the autonomy and rights of subnational governments ${ }^{5}$. In any case, the cooperation of federal entities to carry out collective objectives will depend on institutional incentives, but also the nature of the problems that arise in different government areas.

For its part, Brazilian federalism has incorporated attributes that suggest a high degree of political decentralization, fiscal decentralization and decentralization of authority, particularly for executing social policies by municipalities. But by giving broad legislative authority to the Union and limited veto opportunities to subnational governments ${ }^{8}$, The Brazilian Constitution has allowed the former to exercise a powerful influence on forming the agenda and the formulation of social policies. Therefore, it acted decisively in formatting specific legislation for each area of government, and began to exert federal regulation on the execution of decentralized policies. By concentrating on a higher volume of revenue collection, the Union also took advantage of conditional transfers for subnational governments as incentive for their alignment with the priorities of the Federal Agenda ${ }^{8}$. This alignment has enabled them to overcome coordination problems and the definition of more homogeneous standards of goods and services to be provided under the public policy ${ }^{7}$.

In the case of the health care policy, the need for inter-relationship between the federal entities is even greater than in other areas due to the high level of vertical or horizontal character of the externalities produced from the choices of public managers ${ }^{9}$. In this sense, the SUS was created under a clear conception of cooperation between the three spheres of government ${ }^{10}$, transferring responsibilities to sub-national governments and seeking to overcome competitive and predatory relationships, both between entities of the same level of government, and also of different spheres. The federal coordination has been sustained by a combination of mechanisms, including legal and constitutional constraints - attributions established by Law 8.080/90 and 8.142/90, or obligations of each sphere of government for funding under the Constitutional Amendment 29/2000 and Complementary Law 141/2012 - as well, conditional transfers of resources to states and municipalities have broadened the inducting and regulatory role of the Federal Executive based on the revision of Basic Operational Standards ${ }^{11}$. On the other hand, the use of ministerial decrees have been a valuable, if not the main instrument ${ }^{7}$ for coordinating national health programs, establishing an arrangement in which the federal government occupies a central position, holding power over the agenda and exerting greater influence on the decision-making processes, especially through the Tri-partite Management Commission (CIT), affecting the shape of the cooperation and the allocation of transferred funds while the municipalities are converted into executioners and direct managers of the services that make up the health care system ${ }^{3,8,12}$.

In this context, the development of regionalized health care systems was seen as a condition for achieving equity and comprehensive access, demanding to handle federal issues, since such regional networks go beyond municipal boundaries $^{11-13}$. The establishment of Access Pacts between municipalities under the coordination of state governments had therefore become the main alternative to guarantee the final objectives of SUS, regardless of the municipality in which the citizens resides, and which has come to require an effort of normative construction rules to govern them. The Health $\mathrm{Pact}^{1}$, in force from 2006 to 2011, represents a moment of this construction.

\section{Methodology}

For the purpose of analyzing the formulation and implementation process of the Pact based on the strategic actors involved, we opted for a qualitative study in order to better capture the nuances of the discussion and negotiation process between them, which are still little known in the literature. Semi-structured interviews were conducted between August to December 2013 with a total of eight managers or consultants in the health area who had participated in the process of formulating or implementing the Health Pact while representatives of the National Council of State Health Secretaries (CONASS), the National Council of Municipal Health Secretaries (CONASEMS) or the Federal Ministry of Health $(\mathrm{MoH})$ - CIT component institutions and the object of study, as listed below. The interviews were recorded and transcribed for information analysis while preserving the anonymity of the respondents who, for ethical reasons, will be presented here only by second set numbering. They were complemented by analyzing the reports of the CIT meetings carried out between 2004 and 2012, and the selection criteria was the minutes that carry mention of the Health Pact or the di- 
mensions that comprise it, and excluded those in which the subject was not mentioned (Chart 1).

The content of the interviews were classified into four main categories, being elected based on the following recent developments in Brazilian literature on federalism in order to guide the type of information to be collected and analyzed: the role of "first mover"; control over the discussion agenda; the influence on the formulation or design; and on the implementation process of the Pact. The discussion benefited from categories of the institutionalist approach applied to the analysis of public policies, especially those related to the strategic behavior of actors on the anticipation of distributional effects among themselves in the process of building institutional rules ${ }^{14}$, supported in the discussion on federalism, and intergovernmental coordination and cooperation. The following subsections express the evolution of the institutional building process of the Pact.

\section{Results}

\section{Criticism of operational rules and defining of the problem}

The discussion of a new intergovernmental pact for sharing health management among the three spheres of government began in 2003, during the administration of Minister Humberto Costa ${ }^{15}$, and especially supported in criticizing the Operational Norms for Health Services - NOAS 01/2002. Among the main arguments made at the time which can be highlighted are criticism of its excessively normative and rigid design, which included, for example, the single-center character of the assistance modules, smaller territorial unit of the health region, and excessive detailing of the procedures for formatting the health regions in the states. But only in August 2004, when the 1st Tri-partite Workshop was held at the CIT, it marked the start of discussions on the new pact for regionalizing health care, including a review of its planning tools, management and regulation ${ }^{15}$.

In this first phase, the focus was on aspects related to decentralized management, not including health targets or political commitments that later formed the Pact. The agenda was directed at designing the formulation of a new "Management Pact," as a proposition that circulated between CONASS, CONASEMS and MoH. The goal was to change the logic in the articulation of government spheres in managing the system, requalifying decentralization, regionalization and financing, as well as reviewing the role of ministerial standards in guiding SUS management, as it had been occurring since the BON $01 / 1993^{16}$.

The strongest criticism of the normative and inductive model adopted by the $\mathrm{MoH}$ in health management policy came from CONASEMS, with emphasis on the technical and procedural character and adoption of overly detailed guidelines and procedures that disregarded regional particularities and iniquities. From their point of view, from 2003 the questioning of municipal health secretaries on the inflexibility of municipal management based on the constraints produced by federal regulations were intensified,

Chart 1. People interviewed from August to December 2013.

\begin{tabular}{|c|c|c|}
\hline \multirow[b]{2}{*}{ No } & \multicolumn{2}{|r|}{ Position/function } \\
\hline & $\begin{array}{l}\text { During Health Pact development } \\
\text { and effective start date }\end{array}$ & At the time of the interview \\
\hline 1 & Executive Secretary of CONASS & Coordinator of Institutional development of CONASS \\
\hline 2 & Technical Advisor of CONASS & Technical Advisor of CONASS \\
\hline 3 & President of CONASEMS & CONASEMS Consultant \\
\hline 4 & $\begin{array}{l}\text { Director of the Department of Support for } \\
\text { Decentralization of the Executive Secretary/ } \\
\text { MH ; CIT Coordinator }\end{array}$ & $\begin{array}{l}\text { Director of the Interfederative SGEP/MS Articulation } \\
\text { Department }\end{array}$ \\
\hline 5 & $\begin{array}{l}\text { Municipal secretary of health; CONASSEMS } \\
\text { Advisor; State secretary of health }\end{array}$ & State secretary of health \\
\hline 6 & President of CONASSEMS & Secretary of strategic and participatory management of $\mathrm{MH}$ \\
\hline 7 & President of CONASS & State representative \\
\hline 8 & Executive Secretary of the Ministry of Health & Professor at UNICAMP \\
\hline
\end{tabular}


added to the timid advance of the regionalization process. This assessment was shared by CONASS, which criticized the notarial adherence to the process of regionalization under the current regulations, with little emphasis on "shared solidarity between the three federations" in territorial management ${ }^{17}$. The so-called "solidarity regionalization," then defended, would not in these terms negate municipalization, but overcome it under the new conditions.

CONASS and CONASEMS criticism focused on other related aspects. For CONASS, the difficulty of articulating the regional networks would result from two factors: the form of health management municipalization, which really fragmented the system under the induction of $\mathrm{MoH}$ through financial transfers; and the inheritance of the National Institute of Medical Assistance and Social Welfare (INAMPS), whose hospital network in fact never joined the primary care networks (Respondents 1 and 2). For CONASEMS, the persistence of structural and economic obstacles would have made decentralization into something difficult for the municipalities, because of the large bureaucratic shackles that encumber labor management, and the processes of purchasing, hiring services and making investments. This situation would conflict with solidarity and comprehensiveness, making an instrument such as the Integrated and Joint Plan (PPI) a mere declaratory space without clear sanitary responsibility (Respondent 3 ).

In summary, the national representatives of states and municipalities defended the debureaucratizing of regulatory processes, overcoming the chronic shortage of resources, the defining of sanitary responsibilities and the reversing of access inequities between municipalities and regions. A key point for the new Pact would be to overcome the management by empowering them to be in favor of a proposed pact of health commitments and solidary financing between the spheres of government. It became more and more clear that conflicts in the organization of regional health systems provided for in NOAS were not only restricted to the formulation stage, but persisted in troubles to promote coordination among federal entities, deploy instruments of cooperation and establish health regions ${ }^{17}$.

\section{The Pact as a solution}

The formulation of the bases for the Management Pact was marked by disagreements between CONASS, CONASEMS and $\mathrm{MoH}$, especially on the aspects of management and regulation of the health system ${ }^{16}$.

For $\mathrm{MoH}$, part of its leaders resisted the change in the qualification of municipalities for the agreed commitment model, which would limit their weight in the management of the policy. The idea to adjust and deepen the implementation of NOAS predominated, implementing and strengthening regional deliberative instances ${ }^{1}$. One of the CONASS leaders recalled that in the discussion process there were people who thought that the text of NOAS was better than what was being built ${ }^{17}$, which points to the high degree of divergence for between the actors in negotiation and management, and the yet to come Management Pact. Also, according to one of the statements (Respondent 3) regarding the position of $\mathrm{MoH}$, resistance to the Management Pact especially occurred in the Department of Health, that could experience a loss of power in the new Pact. In addition, the $\mathrm{MoH}$ was prone to dissension and infighting with a large and fragmented structure, which exposed the difficulties of unifying discourse.

Between CONASS and CONASEMS, the main differences concerned sanitary responsibility and regionalization. Regarding the first, CONASEMS kept the defense of the single command on the service providers, subject to a single manager, while CONASS understood that this hindered the protagonist of state health departments (Respondents 1, 2 and 3). The second point concerned "solidarity financing"” which aimed to meet the needs of a health region, something that never advanced (Respondent 3), given the "lack of clarity and viability in form of execution." CONASEMS understood that the financing of primary health care should be a joint participation of the Ministry of Health providing $50 \%$ of the total funds, $25 \%$ by the state and $25 \%$ municipalities. There was also a proposal to establish regional health funds in addition to regional management boards, but there was no consensus on who would be the regional fund manager. For CONASS the States should assume this role through its regional structures; CONASEMS formulated a counterproposal based on Italian experience, according to which the regional college could appoint a secretary or manager of the regional fund by consensus, giving veto power to the States.

Still, regarding the participation in the formation of health revenues, CONASS and CONASEMS had $\mathrm{MoH}$ as a target, pointing to the lack of federal funds as a future hindrance 
to the effective implementation of the Management Pact. On the other hand, $\mathrm{MoH}$ technicians claimed that the funds were already in place federally, and that the Health Pact constituted a driving technology in the new form of management and for building alternatives for better using them. Financial impasse lasted until the final formatting of the Pact proposal, which can largely explain the emergence of the "SUS Defense Pact" component. The latter easily reached consensus, unlike the Pacts for Life and Management. According to one of the statements, the SUS Defense Pact was an ideological component of the process, the driving force of dialogue with society, dialogue with social control, and a fight for funding; it was not something to be formalized, but a movement in defense of the National Health System (Respondent 4). Impasses and relevant conflicts to the financing putting CONASEMS and CONASS on one side, and $\mathrm{MoH}$ on the other, were mitigated by the building of internal cohesion ("in defense of the SUS") in favor of expanding sources of funding ("the Constitutional Amendment 29/2000"), which may have contributed to the completing negotiations.

Another conflicting issue was the flexibility of the conditional allocation of resources transferred to the municipalities, which later led to the grouping of more than 100 transferring mechanisms for specific programs into five funding blocks. CONASEMS' claim is also worth mentioning for the creation of a "Tripartite Internal Affairs Commission" in order to avoid "abuse" by the National Department of SUS Auditing (DENASUS) in monitoring the performance of municipal managers, which was also met.

After the most controversial issues in the negotiations were resolved in 2005, the Minister of Health, in plenary of the $\mathrm{CIT}^{17}$, introduced a change of the name and the scope of the Pact was now composed of three dimensions, being: the Management Pact, the SUS Defense Pact, and the Pact for Life; with the latter defining priorities to be agreed upon and taken over by the three spheres of government, such as appointments around major national targets for SUS ${ }^{18}$. In a way, the name change highlighted the political dimension inherent in the proposed pact, especially the guarantee funds referenced in the Amendment 29/2000, as well as the inclusion of health commitments. The Health Pact was finally signed by the Minister of Health and the presidents of CONASS and CONASEMS in 2006, and published by Decree GM No. 399/2006².

The instrument for formalizing commit- ments among managers and defining goals for the Pact for Life and the Management Pact for the SUS would be the Management Commitment Agreement. Qualification forms established in the Basic Operation Norms (NOB) were made redundant, and modified in the NOAS, which gave the $\mathrm{MoH}$ vertical control over the status of states and municipalities in the SUS through the qualifying verification criteria. On the part of CONASS, there was resistance so that the Management Commitment Terms were signed by the three spheres of government, delaying the signing of the first one. For the municipalities:

The hard part was to convince managers that they could assume that they did not perform such health actions, and that not performing them did not mean that they were weak or fragile, but meant at the moment they did not have the conditions to do so. The management commitment term, the instrument designed for the Management Pact, was a public statement of the management condition for the purpose of assessing the actual condition in which the municipality was in and planning to overcome these limitations (Respondent 4).

Between 2006 and 2012, the Health Pact was the subject of consideration in CIT meetings, from a perspective of monitoring and evaluating the accession process by states and municipalities, as well as in other aspects of its implementation, as highlighted in the next subsection.

\section{Challenges in the implementation}

From 2007, the records of CIT meetings expose reviews of the implementation progress of the Health Pact at a national lev$\mathrm{el}^{13,19,20}$. The Table 1 depicts the process and the adhesion between the years 2006 and 2012 . In the analysis of the series history, it is noteworthy that $82.5 \%$ of the municipalities have joined the Pact throughout the period. Overall, there was not immediate adhesion of States and municipalities, as in 2006 only $1.4 \%$ of the municipalities had done so. At the beginning, "States were hesitant which resulted in a misunderstanding when municipalities began to celebrate the Pacts themselves" (Respondent 5). According to this informant, some states and municipalities had only joined the Pact in a symbolic way by signing the Management Commitment Agreement.

Different rates in the adherence movement have been observed over the six years since the Pact has been enforced, with two periods of greater support from states and municipalities to the proposal: $2007 / 2008$ and 2010 . Of the total 
Table 1. Municipal Adherence to the Health Pact. Brazil, 2006 to April, 2012.

\begin{tabular}{|c|c|c|c|c|c|c|c|c|c|c|}
\hline \multirow{2}{*}{$\begin{array}{l}\text { F.U. (federal } \\
\text { unit) }\end{array}$} & \multicolumn{7}{|c|}{ Year of adherence to the Pact } & \multirow{2}{*}{ Total } & \multirow{2}{*}{$\begin{array}{l}\text { Municipali- } \\
\text { ties of the } \\
\text { F.U. }\end{array}$} & \multirow{2}{*}{$\begin{array}{c}\% \\
\text { Adherence }\end{array}$} \\
\hline & 2006 & 2007 & 2008 & 2009 & 2010 & 2011 & 2012 & & & \\
\hline $\mathrm{AC}$ & 0 & 1 & 2 & 1 & 5 & 2 & 0 & 11 & 22 & 50.00 \\
\hline $\mathrm{AM}$ & 0 & 0 & 1 & 0 & 2 & 1 & 0 & 4 & 62 & 6.45 \\
\hline $\mathrm{AP}$ & 0 & 0 & 0 & 0 & 6 & 0 & 0 & 6 & 16 & 37.50 \\
\hline $\mathrm{PA}$ & 0 & 0 & 0 & 0 & 131 & 3 & 0 & 134 & 143 & 93.71 \\
\hline RO & 0 & 0 & 33 & 10 & 9 & 0 & 0 & 52 & 52 & 100.00 \\
\hline $\mathrm{RR}$ & 0 & 1 & 5 & 2 & 1 & 0 & 0 & 9 & 15 & 60.00 \\
\hline TO & 0 & 39 & 0 & 9 & 19 & 11 & 6 & 84 & 139 & 60.43 \\
\hline Norteh & 0 & 41 & 41 & 22 & 173 & 17 & 6 & 300 & 449 & 66.82 \\
\hline $\mathrm{AL}$ & 0 & 25 & 18 & 17 & 31 & 7 & 4 & 102 & 102 & 100.00 \\
\hline BA & 1 & 14 & 21 & 54 & 152 & 24 & 22 & 288 & 417 & 69.06 \\
\hline $\mathrm{CE}$ & 56 & 111 & 8 & 6 & 3 & 0 & 0 & 184 & 184 & 100.00 \\
\hline MA & 1 & 5 & 82 & 11 & 26 & 23 & 6 & 154 & 217 & 70.97 \\
\hline $\mathrm{PB}$ & 0 & 1 & 3 & 67 & 69 & 40 & 6 & 186 & 223 & 83.41 \\
\hline $\mathrm{PE}$ & 2 & 2 & 5 & 1 & 97 & 30 & 20 & 157 & 184 & 85.33 \\
\hline PI & 0 & 0 & 0 & 3 & 21 & 35 & 0 & 59 & 224 & 26.34 \\
\hline $\mathrm{RN}$ & 0 & 19 & 125 & 20 & 3 & 0 & 0 & 167 & 167 & 100.00 \\
\hline $\mathrm{SE}$ & 0 & 0 & 0 & 0 & 0 & 75 & 0 & 75 & 75 & 100.00 \\
\hline Northeast & 60 & 177 & 262 & 179 & 402 & 234 & 58 & 1,372 & 1,793 & 76.52 \\
\hline ES & 0 & 1 & 38 & 16 & 16 & 0 & 0 & 71 & 78 & 91.03 \\
\hline MG & 0 & 622 & 166 & 9 & 10 & 21 & 13 & 841 & 853 & 98.59 \\
\hline RJ & 0 & 18 & 7 & 13 & 10 & 2 & 4 & 54 & 92 & 58.70 \\
\hline SP & 3 & 519 & 121 & 1 & 0 & 1 & 0 & 645 & 645 & 100.00 \\
\hline Southeast & 3 & 1,160 & 332 & 39 & 36 & 24 & 17 & 1.611 & 1,668 & 96.58 \\
\hline PR & 0 & 296 & 93 & 10 & 0 & 0 & 0 & 399 & 399 & 100.00 \\
\hline RS & 0 & 0 & 0 & 1 & 40 & 90 & 24 & 155 & 496 & 31.25 \\
\hline $\mathrm{SC}$ & 0 & 1 & 97 & 59 & 136 & 0 & 0 & 293 & 293 & 100.00 \\
\hline South & 0 & 297 & 190 & 70 & 176 & 90 & 24 & 847 & 1,188 & 71.30 \\
\hline DF & NSA & NSA & NSA & NSA & NSA & NSA & NSA & NSA & NSA & NSA \\
\hline GO & 0 & 10 & 63 & 43 & 102 & 28 & 0 & 246 & 246 & 100.00 \\
\hline MS & 0 & 78 & 0 & 0 & 0 & 0 & 0 & 78 & 78 & 100.00 \\
\hline MT & 0 & 1 & 75 & 25 & 28 & 1 & 5 & 135 & 141 & 95.74 \\
\hline Center-West & 0 & 89 & 138 & 68 & 130 & 29 & 5 & 459 & 465 & 98.71 \\
\hline Brasil & 63 & 1,764 & 963 & 378 & 917 & 394 & 110 & 4,589 & 5,563 & 82.49 \\
\hline
\end{tabular}

Source: ST-CIT/SGEP/MS.

municipalities that have joined the pact, $60 \%$ did so in the years 2007-2008, which may have been motivated by the regulatory transfer of federal funds to support the regionalization of actions. A fund to fund transfer totaling the amount of $\mathrm{R} \$ 20,000$ for the Regional Management Councils (CGR) was expected upon the approval of Management Commitment Terms. In 2009 there was a slowdown in the process, with adhesion of just $8 \%$ of the municipalities. One of the possible explanations would be the management changes of municipalities resulting from the election results $^{21}$. In 2010, another 917 municipalities joined the Pact, representing 20\% total adhesion.

Based from the standpoint of average financing of high complexity procedures and other components for the construction of regionalized care networks, there were no significant changes. According to one of the respondents, at that time, "the Pact proposed solidarity-based financing that did not happen," and there was not an increase in state spending on the SUS, nor were additional funds from the Amendment 29/2000 reversed in advancing regionalization (Respondent 5). The underfunding has remained, being denounced by CONASS and CONASEMS, which 
pointed to a disparity between goals proposed by the Pact and the available budget for health.

Still in 2009, the priorities and objectives of the Pact for Life were resumed to review the purpose of monitoring and evaluating indicators, guidelines, deadlines and directive for the pact. According to two statements, there was great pressure to increase the number of indicators, since all Ministry areas wanted "to find themselves in the indicators" (Respondents 1 and 2). This would explain the presence of a significant number of indicators (then 54), some universal alongside specific others, such as indigenous health and diseases of regional prevalence. The pact would have made the purpose of building a network, a system, moving to prioritize impact indicators and concern for the goals, "particularly in the Pact for Life" (Respondent 4).

Two aspects draw attention regarding the goals and indicators; first, the declaratory nature of the records that informed compliance and not the goals; the other being the clear lack of consequences for not meeting the goals by federal entities. For the $\mathrm{MoH}$, there was no concern to evaluate the correctness of the reported data; and the failure of goals was to be justified in the management reports of federal entities and some federal programs later put forth "some incentive for results" (Respondent 4).

In the process of implementing the Health Pact, there was significant reduction in the dialogues and discussions within the CIT. According to one of the respondents, (Respondent 2), the $\mathrm{MoH}$ "has positioned itself in an autocratic way, changing the nature of the tripartite forum, from a political and institutional character, for a more administrative role." A more democratic and political space of collective construction, in the view of this actor, the CIT has become a more bureaucratic space for debate on fragmented policies, differing from a space to discuss structural issues of the system ${ }^{21}$. Another problem convergent with this assessment, refers to the lack of coordination between the mechanisms of management and state and local health plans. According to another statement:

If on the one hand TCG intended to clarify the actual management condition of states and municipalities, it was not integrated with a key instrument, which was the municipal and state health plan ... a large number of instruments remain which do not open dialogue. Today, they are integrating the national plan guidelines to the contract guidelines in order to minimize these problems (Respondent 4).
In summary, the respondents agree about regionalization not advancing under the Health Pact, especially regarding the increase of "regional governance," understood as a process of negotiation, cooperation and decision between the federal autonomous entities in a specific territorial space.

\section{Criticism of the Health Pact and the birthplace of COAP}

In the view of one of the masterminds of the Pact, the initial idea was less focused on management goals and more on the articulation of health regions based on the planning and investment in training of care networks, however this goal would have been lost over time (Respondent 5). The original bet was that the "cement" of this regional organization was molded from two essential components: inter-manager sharing and solidarity, not by the force of law, as subsequently presented by the proposal of Decree 7.508/2011, thus establishing the COAP.

Regardless of the progress made, such as the establishment of regional boards and better definition of health regions, the essential objectives of the Health Pact, particularly the Management component, have not been achieved. This was the view of many respondents, for which there was no overcoming SUS bottlenecks, or "structural problems," such as the issues of being underfinanced and understaffed. Specifically in relation to the SUS Defense Pact, one respondent described the reasons for its failure:

The SUS Defense Pact essentially had two major goals; first, as a process of inclusion of civil society in the health care policy, which has not been incorporated yet. The health plan remains an illusion of the Brazilian middle class. The other was that the funding has not yet reached its goal, which is to have 6 to $7 \%$ of GDP being spent on health (Respondent 7).

Another obstacle would have been the discontinuation of government administrations, hindering the necessary build-up for the processes of change, causing the loss of institutional memory and forcing review of previously signed agreements. According to another respondent:

70\% of municipal secretaries in Brazil in January 2013 were new managers who had never been health secretaries [...] Municipal Advisors with low levels of experience, who do not know what a law is, who do not understand/know the system. How can such a complex machine, that lacks fast decision-making, afford to change and start from 
scratch? This affects the Ministry less because $\mathrm{MoH}$ has slightly longer cycles of permanence, especially when you can keep governments for longer (Respondent 4).

In 2012, Appointment Term approvals were replaced by the signature of Public Action Contracts (COAP) $)^{22}$, a tool for legally formalizing the responsibilities of federal entities, with the intention that the legal and judicial system operates in honoring the guarantees of compliance with the signed agreements. "The idea was that the COAP would replace the Health Pact with a permanent methodology of intergovernmental integration which would reduce the fragmentation of health management" (Respondent 4). At the end of Lula's government, under the management of Minister Temporão, it was prepared a draft of what later in the Dilma government eventually became Decree 7508/201122. At that time, the involvement of CONASS and CONASEMS in the discussion was only punctual. Adjustments were unilaterally processed in $\mathrm{MoH}$ and Civil House, and when the proposal was brought to the CIT, "it arrived almost finished" (Respondent 5). The discussion in the CIT was concluded in two days, and it did not return to this forum for the closing of the final proposal, as the CONASS and CONASEMS were aware of its publication in the Official Federal Gazette.

This event marked an important change in the conduction and coordination of health policy by the $\mathrm{MoH}$ with lower participation and dialogue within the CIT, which began in the management of the Minister Temporão and accentuated in the management of the Minister Padilha:

The merit of the Pact is that the measure would be building and would be legitimizing, the COAP decree, not that this is illegitimate, it had difficulty being accepted because there was no participation, having not been discussed with the states and municipalities [...]. When CONASS attended the COAP discussion at the beginning of the year, they pointed out that the Pact should not be abandoned, that there had to be continuity, that the Pact could not be thrown away, and to prioritize everything that had been built, the issue of regionalization which had been managed to be inserted, and this was respected (Respondent 5 ).

COAP also did not include any referral to the financing problem, not bringing forth any new features or changes in the SUS fund transfer system. Its adherence was more restricted and slower than to the Pact, according to information provided by various respondents.

\section{Discussion}

Under the profile proposed in this paper, some aspects of the institutional construction of the Health Pact have been identified which have not yet been discussed in specific literature, although certain aspects which are highlighted further on present convergences with the literature.

Although the literature on the Brazilian federalism currently shows the Union as having an agenda of initiative and formulation of policies and programs on a national scale since the mid1990s, the case described in part confirms this thesis, but also points to the reasonable influence of representations of subnational governments in this process. The time gap between the start of President Lula's first management and the first meeting to discuss the Pact, including CONASS and CONASEMS - only held in August 2004 suggests that the internal maturation process of a proposal by the $\mathrm{MoH}$ was not simple and that there were probably different perspectives in the evaluation of NOAS among MoH sectors. Moreover, in March 2004 CONASEMS had already submitted a platform of points to be addressed in an eventual revision of the regionalization policy for the SUS. Apparently, the unitary actor $(\mathrm{MoH})$ had many internal divisions while the diffuse collective actor as CONASEMS, representation of thousands of Brazilian municipalities, was relatively cohesive around a discussion agenda, but still, the process effectively only began when the $\mathrm{MoH}$ was presented as the "first mover" and guided the discussion at the CIT.

Secondly, the statements collected and the analysis of the documents testify that the long period of discussions to redesign the Health Pact - between August 2004 and early 2006, when it was published - reflected a high degree of dissent about the changes to be implemented. $\mathrm{MoH}$ had to give control over the activation states and municipalities that would assign them different status from receiving the resources and exercise of management autonomy, and gave in points such as the creation of the tripartite internal affairs to "control" the activities of the National Auditing of the SUS. States and municipalities differed in the single command, and the discussion as to who would take over the management of financial resources if transferred to the health regions. Although, the evolution of the discussion on multilateral proposals and counterproposals suggests a reasonable level of horizontality in the construction of the rules of the Health Pact, rather than unilateral control of the agenda by the 
$\mathrm{MoH}$; however, the uptake of proposals made by CONASEMS and the CONASS found hard limits, for example, in the issue of funding. Without the regulation of EC29/2000, and unlike the states and municipalities, the $\mathrm{MoH}$ was not constrained by constitutional or legal regulations to significantly increase the revenue that was destined to health, and did not give in to expanding their levels of participation in health with public revenues.

Thirdly, unlocking the impasse on the funding - since neither CONASS nor CONASEMS accepted a pact without new federal resources seems to be the best explanation for the aggregation component of the "SUS Defense Pact" to the Health Pact. Thus, it was transferred in this way to become a political compromise to be made in future by the three spheres of government to fight the expansion of funding sources via regulation of EC 29/2000; the solution of the problem which then prevented the continuation of the Pact, leaving the implementation of the "logic of financial cooperation" open, a condition which added to the upward planning, and could indeed lead to correct inequalities, giving it meaning and effectiveness ${ }^{23}$.

The increased number of indicators in the goals of the Pact for Life is also worth considering, including the general nature alongside other specifics, which seems to have met the expectations of specific bureaucracies from $\mathrm{MoH}$, perceiving themselves threatened on the verge of not having their areas covered with future investments that could be targeted to achieving the goals. The absence of enforcement mechanisms to meet the goals could match, in assumption, to accommodating the absence of new federal resources and, hence, a way to avoid possible tensions that would result from any penalties to states or municipalities that had not reached the goals. The position of giving a more "ritualistic" treatment to the subjects of the Pact by the $\mathrm{MoH}$, as present in the statements, converges to other perceptions as "autocratic" or insulating positions of the $\mathrm{Na}$ tional SUS coordinator, apparently being even more salient in the formulation process of the COAP, according to statements collected.

Finally, despite the formal accession to the pact by states and municipalities, assessments taken from the minutes of CIT and the testimonies show that the Health Pact would not have been able to modify the dynamics of federal relations in the intended direction, mainly regarding the conformation of regional health care net- works, which was the objective of the Management Pact. These findings converge in the same direction of other studies, meaning to point out the limitations of the institutional design of the Pact in the induction of horizontal cooperation among government entities ${ }^{24}$ or its strategies and tools to advance, per se, the decentralization and regionalization of health in the Brazilian states ${ }^{2}$, or the influence of the process of structural factors of regional scope (the availability of financial and human resources, as well as capacity), and political and managerial factors related to the performance of the state-level government as inductor or process coordinator ${ }^{2}$. A point to be explored in future studies refers to the elucidation of the impact that the addition of new federal funds or discontinuity in government management, especially in $\mathrm{MoH}$, would have produced on the guarantee of the material and political foundations of this process.

\section{Conclusion}

Although under the coordination of the Ministry of Health, the institutional construction of the Management Pact has undergone a significant influence of the state and municipal levels, and the high degree of dissent about the various dimensions of the Health Pact, even inside the federal bureaucracy, generated an extended and tortuous negotiation process, in which the parties were not indifferent to the implications that the rules under discussion would bring to the performance of their respective functions in the Unified Health System (SUS). Concessions made from both sides, however, do not seem to be enough, according to the statements collected in this study and despite incremental advances in order for the Pact to modify the dynamics of federal relations in the direction previously announced by the parties to the beginning of its construction process. By specifically dealing with the institutional construction of the Pact and the consequences of it in the tripartite pact arena, thus drawing upon the convergence of identification and contrasts between visions of the actors involved, and between them and the mobilized documents, this work does not mobilize empirical evidence in order to confirm or deny this proposition. Their contribution, however, reinforces the need to persist with an agenda that will accomplish such purpose. 


\section{Collaborations}

TMG Menicucci, LA Costa and JA Machado participated in the design and research that gave rise to this article, and its writing of it.

\section{Acknowledgements}

The research received financial aid from Fapemig and CNPQ. We give thanks for the comments from Marta Arretche about the first version of the article, presented in the Brazilian Political Science Association meeting and anonymous reviewers whose suggestions contributed to the improvement of this article. 


\section{References}

1. Brasil. Portaria ${ }^{\circ} 399$, de 22 de fevereiro de 2006. Divulga o Pacto pela Saúde 2006 - Consolidação do SUS e aprova as Diretrizes Operacionais do Referido Pacto. Diário Oficial de União 2006; 22 fev.

2. Lima L, Queiroz L, Machado C, Viana A. Descentralização e regionalização: dinâmica e condicionantes da implantação do Pacto pela Saúde no Brasil. Cien Saude Colet 2012; 17(7):1903-1914

3. Menicucci TMG. Cooperação e coordenação na implementação de políticas públicas: as relações intergovernamentais na regionalização da assistência à saúde. Belo Horizonte: UFMG; 2013.

4. Souza C. Federalismo: teorias e conceitos revisitados. BIB - Revista Brasileira de Informação Bibliográfica em Ciências Sociais 2008; 65:27-48.

5. Abrúcio FL. A coordenação federativa no Brasil: a experiência do período FHC e os desafios do governo Lula. Rev. Sociol. Polit. 2005; 24:41-67.

6. Rodden J. Federalismo e descentralização em perspectiva comparada: sobre significados e medidas. Rev. Sociol. Polit. 2005; 24:9-27.

7. Arretche MTS. Federalismo e políticas sociais no Brasil: problemas de coordenação e autonomia. São Paulo Perspec 2004; 18(2):17-26.

8. Arretche MTS. Democracia, federalismo e centralização no Brasil. Rio de Janeiro: FGV, Fiocruz; 2012.

9. Oates WE. An Essay on Fiscal Federalism. JEL 1999; 37(3):1120-1149.

10. Viana ALD, Lima LD, Oliveira RG. Descentralização e federalismo: a política de saúde em novo contexto - lições do caso brasileiro. Cien Saude Colet 2002; 7(3):493-507.

11. Levcovitz E, Lima LD, Machado CV. Política de saúde nos anos 90: relações intergovernamentais e o papel das Normas Operacionais Básicas. Cien Saude Colet 2001; 6(2):269-291.

12. Menicucci TMG, Marques AMF, Oliveira BR, Fortes FBCT, Moreira LMC, Duarte VC. Regionalização da atenção à saúde em contexto federativo e suas implicações para a equidade de acesso e a integralidade da atenção. Belo Horizonte: FJP; 2008.

13. Brasil. Ministério da Saúde (MS). Resumo Executivo da Reunião Ordinária da Comissão Intergestores Tripartite do dia 27 de outubro de 2007. Brasília: MS; 2007.

14. Scharpf FW. Games Real Actors Play: actor-centered institucionalism in policy research. Boulder: Westview Press, 1997.

15. Brasil. Ministério da Saúde (MS). Resumo Executivo da Reunião Ordinária da Comissão Intergestores Tripartite do dia 17 de novembro de 2003. Brasília: MS; 2003.
16. Brasil. Ministério da Saúde (MS). Anexo VI Pacto de Gestão do Sistema Único de Saúde: Proposta do Ministério da Saúde para a definição de Compromissos com ações de curso prazo. In: Resumo Executivo da Reunião Ordinária da Comissão Intergestores Tripartite do dia 21 de outubro de 2004. Brasília: MS; 2004.

17. Brasil. Ministério da Saúde (MS). Resumo Executivo da Reunião Ordinária da Comissão Intergestores Tripartite do dia 18 de março de 2005. Brasília: MS; 2005.

18. Brasil. Ministério da Saúde (MS). Resumo Executivo da Reunião Ordinária da Comissão Intergestores Tripartite do dia 26 de Janeiro de 2006. Brasília: MS; 2006.

19. Brasil. Ministério da Saúde (MS). Resumo Executivo do Reunião Ordinária da Comissão Intergestores Tripartite do dia 11 de setembro de 2008. Brasília: MS; 2008.

20. Lima LD, Queiroz LFN. O processo de descentralização e regionalização do SUS no contexto do Pacto pela Saúde. In: Machado CV, Baptista TWF, Lima LD, organizadores. Políticas de saúde no Brasil: continuidades e mudanças. Rio de Janeiro: Fiocruz; 2012. p. 1903-1914.

21. Costa LA. Insulamento burocrático, autonomia do estado e inserção social: um estudo do ministério da saúde na coordenação nacional do SUS [dissertação]. Belo Horizonte: Universidade Federal de Minas Gerais; 2011.

22. Brasil. Decreto no 7.508 de 28 de junho de 2011. Regulamenta a Lei no 8.080, de 19 de setembro de 1990, para dispor sobre a organização do Sistema Único de Saúde - SUS, o planejamento da saúde, a assistência à saúde e a articulação interfederativa, e dá outras providências. Diário Oficial da União 2011; 28 jun.

23. Trevisan LN, Junqueira LA. Construindo o "pacto de gestão" no SUS: da descentralização tutelada à gestão em rede. Cien Saude Colet 2007; 12(4):893-902.

24. Machado J. Pacto de Gestão na Saúde: Até onde esperar uma "regionalização solidária e cooperativa"? Revista Brasileira de Ciências Sociais 2009; 24(71):105-120.

Article submitted 11/09/2015

Approved 16/12/2015

Final versions submitted 18/12/2015 